\title{
Penerapan uji Q Cochran terhadap Atribut Produk Laptop Menggunakan Multiple Response Analysis (MRA)
}

\section{Dilla Oktoriandi*}

Prodi Statistika, Fakultas Matematika dan Ilmu Pengetahuan Alam, Universitas Islam Bandung, Indonesia.

*dillaoktoriandi@gmail.com

\begin{abstract}
In Multiple Response Analysis using frequency tables and cross tabulations, in which there are several data sets of specified responses. In MRA data, researchers often have difficulty determining which responses are most important. To deal with this problem, an alternative Cochran $\mathrm{Q}$ statistical test is given. MRA is commonly used for research to select important things, one example is the problem of a product that is considered important by consumers. Laptop or notebook products are one of the electronic products that are the center of attention. One of the users is students, because it is used to support the learning process. The brand image of a product becomes important as an advantage in making products. The brand image of a product can be built from product attributes. There are several attributes that are determined to form a brand image on a laptop, namely price, color, design, brand, facilities and specifications. From the earnings, MRA gets the three most attributes, namely Specifications, Price and Design. According to the Cochran Q test, it detects if there is a difference in the estimates of the third attribute with the $\mathrm{Q}$ test statistic $=11,404$ with $\mathrm{p}$-value $=0.003$. In this case a post hoc analysis is required to determine the exact difference in the proportion of pairs. This pair can be detected using McNemar's test paired with Bonferroni Correction resulting in one pair of attributes namely Specification with a value of $0.0011<0.017$. From the results of the odds ratio, it shows that the tendency to be in the attribute specification is 3.86 times more important than the attribute price. In other words, in this case the specification is the attribute that is considered the most important in shaping the product brand image on a laptop.
\end{abstract}

Keywords: Product Attributes, Multiple Response Analysis (MRA), Q Cochran..

Abstrak. Dalam penyelesaian Multiple Response Analysis menggunakan tabel frekuensi dan tabulasi silang, yang didalamnya terdapat beberapa data set respon yang sudah ditentukan. Pada data MRA para peneliti sering kali mengalami kesulitan dalam menetapkan tanggapan responden apa saja yang paling penting. Untuk menangani masalah tersebut, diberikan suatu alternatif uji statistik Q Cochran. MRA biasa digunakan untuk penelitian memilih hal yang penting terhadap suatu masalah salah satu contohnya adalah penentuan atribut dari suatu produk yang dianggap penting oleh konsumen. Produk laptop atau notebook merupakan salah satu produk elektronik yang menjadi pusat perhatian. Salah satu penggunanya yaitu mahasiswa, karena digunakan untuk menunjang proses pembelajaran. Citra merek suatu produk menjadi penting sebagai keunggulan dalam membuat produk. Citra merek suatu produk dapat dibangun dari atribut produk. Adapun beberapa atribut yang ditentukan untuk membentuk citra merek pada suatu laptop yaitu harga, warna, desain, merek, fasilitas dan spesifikasi. Dari perholehan MRA mendapatkan tiga atribut terbanyak yaitu Spesifikasi, Harga dan Desain. Menurut pengujian Cochran Q mendeteksi jika terdapat perbedaan proporsi tanggapan dari ketiga atribut dengan Statistik uji $Q=11,404$ dengan $p$-value $=0,003$. Dalam kasus ini diperlukan analisis post hoc untuk menentukan perbedaan yang tepat dalam proporsi berpasangan. Perbedaan berpasangan ini dapat dideteksi dengan menggunakan uji McNemar berpasangan dengan Koreksi Bonferroni mengghasilkan satu pasang atribut yaitu Spesifikasi dengan harga dengan hasil 0,0011 < 0,017 . Dari hasil perolehan odds ratio menunjukan kecenderungan berada pada atribut spesifikasi lebih penting sebesar 3,86 kali dari atribut harga. Dengan kata lain bahwa dalam kasus ini spesifikasi merupakan atribut yang dianggap paling penting dalam membentuk citra merek produk pada suatu laptop.

Kata Kunci: Atribut Produk, Multiple Response Analysis (MRA), Q Cochran. 


\section{A. Pendahuluan}

Pada penyelesaian Analisis Respon Ganda atau biasa disebut Multiple Response Analysis (MRA) menggunakan tabel frekuensi dan tabulasi silang, yang didalamnya terdapat beberapa data set respon yang sudah ditentukan. Dalam menganalisis dan mentabulasi data Multiple Response Analysis (MRA) dipandang sulit, karena begitu banyak kategori yang dipilih responden yang beririsan satu sama lain. Pada data MRA para peneliti sering kali mengalami kesulitan dalam menetapkan tanggapan responden apa saja yang paling penting. Untuk menangani masalah tersebut, diberikan suatu alternatif uji statistik Q Cochran(1). Uji Q Cochran digunakan untuk menguji perbedaan proporsi pada sampel berpasangan yang melibatkan sejumlah opsi. Operasional uji Q Cochran untuk data yang diperoleh dari MRA, memerlukan pengkodean dikotomus. MRA biasa digunakan untuk penelitian memilih hal yang penting terhadap suatu masalah salah satu contohnya adalah penentuan atribut dari suatu produk yang dianggap penting oleh konsumen.

Pentingnya memahami perilaku konsumen yang telah menjadi pusat perhatian di berbagai macam industri, salah satunya dalam industri elektronik yang terus menerus meningkat di berbagai bidang. Dengan diikutinya perkembangan kemajuan teknologi yang dirasakan saat ini, laptop atau notebook merupakan salah satu produk elektronik yang menjadi pusat perhatian. Dimana semua kalangan pasti menggunakan laptop sebagai sarana untuk membantu pekerjaan dan pembelajaran. Terutama mahasiswa, karena laptop atau notebook merupakan sebuah alat untuk menunjang pembelajaran. Konsumen tidak sembarangan dalam membeli laptop atau notebook, banyak aspek yang dipertimbangkan terkait laptop yang dipilih. Hal tersebut membuat produsen harus memiliki strategi pemasaran yang tepat supaya bisa bertahan dan sukses dalam bersaing. Citra merek suatu produk menjadi penting sebagai keunggulan dalam membuat produk. Untuk mengetahui citra merek yang ada dibenak komsumen terhadap laptop sebagai keunggulan tersendiri, perusahaan membutuhkan salah satu komponen dari Brand Equity yaitu Brand Association(2).

Brand Association merupakan suatu kesan yang tercipta dari ingatan seseorang atas suatu merek, yang dibangun dari atribut produk. Atribut produk merupakan unsur-unsur produk yang dianggap penting oleh konsumen dan dijadikan sebagai dasar untuk pengambilan keputusan pembelian (3). Adapun atribut produk dalam penelitian ini untuk produk latop yaitu meliputi merek, harga, warna, desain, fasilitas dan spesifikasi(4). Dalam penelitian ini akan ditentukan atribut apa saja yang dianggap penting oleh konsumen dalam membentuk citra merek suatu laptop melalui perbandingan proporsi tanggapan responden terhadap atribut yang dipilih. Penelitian dilakukan kepada mahasiswa program studi Statistika FMIPA Universitas Islam Bandung.

Berdasarkian latar belakang diatas, maka masalah yang dapat diidentifikasikan sebagai berikut:

1. Bagaimana membentuk tabulasi data MRA?

2. Bagaimana uji perbandingan proporsi tanggapan responden terhadap atribut yang dipilih?

Selanjutnya, tujuan dalam penelitian ini diuraikan dalam pokok-pokok sbb.

1. Untuk mengetahui bagaimana membentuk tabulasi data MRA.

2. Untuk mengetahui bagaimana uji perbandingan proporsi tanggapan responden terhadap atribut yang dipilih.

\section{B. Metodologi Penelitian}

\section{Multiple Response Analysis (MRA)}

Dalam penyelesaian Analisis Respon Ganda atau biasa disebut Multiple Response Analysis menggunakan tabel frekuensi dan tabulasi silang, yang didalamnya terdapat beberapa data set respon yang sudah ditentukan. Data set respon berisikan semua tanggapan yang dihasilkan dari penelitian atau survei. Kemudian serangkaian tanggapan tersebut diambil untuk dijadikan beberapa variabel dikotomi. Tanggapan kosong tidak boleh dianggap sebagai data yang hilang, karena hal tersebut merupakan salah satu asumsi penting saat melakukan survei yang melibatkan beberapa item tanggapan(5). 
Data untuk pertanyaan ini dicatat dalam beberapa kolom, dengan satu kolom per opsi jawaban. Jika seseorang memilih opsi tersebut maka diberi nilai "1" dan untuk tidak memilih opsi tersebut diberi nilai "0". Hasil dari MRA yaitu untuk mengetahui perolehan responden yang memilih jawaban pada opsi yang dipilih ataupun responden yang ingin mengetahui opsi yang tidak dipilih. Dari hasil opsi yang dipilih atau tidak dipilih bisa disajikan dengan bentuk tabel.

\section{Uji Q Cochran}

Uji Q Cochran untuk k sampel berpasangan, menyediakan sebuah cara untuk menguji apakah tiga kelompok frekuensi atau lebih untuk sampel berpasangan saling berbeda signifikan diantara kelompok tersebut. Konsep berpasangan dapat didasarkan atas ciri-ciri yang relevan dalam subyek-subyek yang diamati, atau berdasarkan kenyataan bahwa subyek-subyek yang sama dipakai dibawah kondisi-kondisi yang berbeda. Tes Cochran ini sangat cocok jika data skala pengukurannya nominal dikotomi(6).

Dalam uji Q Cochran terdapat dua penilaian atau dikotomi yang berlawanan, yaitu berhasil atau gagal, ya atau tidak dan lain-lain. Variabel yang dihitung berasal dari orang yang sama atau individu yang sesuai. Data yang digunakan untuk analisis Q Cochran yaitu berbentuk biner, artinya 1 untuk keberhasilan dan 0 untuk kegagalan. Cara perhitungan uji Q Cochran seperti pada rumus atau persamaan (2.1).

Adapun hipotesis untuk menguji apakah ada berbedaan respon diantara k kelompok sampel sebagai berikut:

$\mathrm{H}_{0}: \pi_{1}=\pi_{2}=\cdots=\pi_{\mathrm{k}}$, proporsi tanggapan sama disemua atribut

$\mathrm{H}_{1}$ : minimal 1 tanda sama dengan tidak berlaku, proporsi tanggapan berberbeda disemua atribut

$$
Q=\frac{(k-1)\left[k\left(\sum_{j=1}^{k} G_{j}^{2}\right)-\left[\sum_{j=1}^{k}\left(G_{j}\right)^{2}\right]\right]}{k\left(\sum_{i=1}^{N} L_{i}\right)-\left(\sum_{i=1}^{N} L_{i}^{2}\right)}
$$

Dimana:

$\mathrm{Q}=$ Nilai Cochran test

$\mathrm{K}=$ Banyaknya Atribut

$\mathrm{Gj}=$ Jumlah keseluruhan "dipilih" dalam kolom ke-j

$\mathrm{Li}=$ Jumlah keseluruhan "dipilih" dalam baris ke-i

Kriteria uji dari pengujian hipotes yang dilakukan adalah tolak H0 jika Q $>\chi 2\{\alpha$; (k1)\}, dimana $\alpha$ adalah taraf arti yang ditetapkan oileh peneliti. Apabila Uji Q Cochran signifikan, analisis post-hoc dilakukan dengan melakukan analisis McNemar koreksi Bonferroni(1).

\section{Uji Lanjutan (Post Hoc)}

Pada uji lanjut atau biasa disebut post hoc dalam uji Q Cochran biasanya menggunakan uji McNemar. Namun, Uji lanjutan McNemar ini akan digunakan bersama Koreksi Bonferroni ketika terdapat perbedaan proporsi yang signifikan dari hasil uji Q Cochran. Oleh karena itu fungsi dari uji Mcnemar disini untuk mencari perbedaan antara masing-masing pasangan. Koreksi bonferroni digunakan agar membatasi keasalahan pada tipe 1.

1. Uji McNemar dengan Koreksi Bonferroni

Dalam pengujian McNemar digunakan untuk menguji perbedaan proporsi yang signifikan antara dua kelompok yang berpasangan yang mana hanya memiliki dua kategori. Terdapat sebuah hipotesa untuk diujikan apakah terdapat perbedaan antara dua sampel berpasangan yang berasal dari atau mewakili dua kelompok. Uji McNemar dapat digunkan jika datanya mempunyai skala pengukuran nominal atau dikotomi. Uji McNemar dapat dibentuk dengan menggunakan tabel 2x2 atau biasa disebut dengan tabel kontingensi seperti yang disajikan pada tabel 2.2(7). 
Tabel 1. Model Uji McNemar

\begin{tabular}{|c|l|c|c|c|}
\hline \multicolumn{2}{|c|}{} & \multicolumn{2}{c|}{ Atribut 2 } & \multirow{2}{*}{ Penjumlahan } \\
\cline { 3 - 5 } & Respon & Respon & baris \\
kategori 1 & kategori 2 & \\
\hline \multirow{2}{*}{ Atribut1 } & Respon kategori 1 & $a$ & $b$ & $\boldsymbol{a}+\boldsymbol{b}=\boldsymbol{n}_{1}$ \\
\cline { 2 - 5 } & Respon kategori 2 & $c$ & $d$ & $\boldsymbol{c}+\boldsymbol{d}=\boldsymbol{n}_{2}$ \\
\hline & Penjumlahan kolom & $\boldsymbol{a}+\boldsymbol{c}$ & $\boldsymbol{b}+\boldsymbol{d}$ & $\boldsymbol{n}=\boldsymbol{n}_{\boldsymbol{I}}+\boldsymbol{n}_{2}$ \\
\hline
\end{tabular}

Jumlah penelitian dapat ditunjukan pada sel $a, b, c$, dan $d$ disetiap kemungkinan kategori diperlukan untuk menunjukan dua jenis respon subyek. Pada pengujian McNemar, sel yang diperhatikan adalah $b$ dan $c$ karena sel tersebut mempunyai perbedaan respon terhadap dua kondisi dengan derajat kebebasan $(\mathrm{df})=1$. Berdasarkan informasi yang didapatkan dari eksperimen dibuatlah hipotesis sebagai berikut(7):

$H_{0}: \pi_{c}=\pi_{b}$, tidak ada perbedaan antara kedua proporsi pada sel $b$ dan sel $c$

$H_{1}: \pi_{c} \neq \pi_{b}$, ada perbedaan antara kedua proporsi pada sel $b$ dan sel $c$

Dalam melakukan pengujian McNemar apabila nilai terdapat frekuensi harapan dengan dihitung menurut persamaan berikut ini:

$$
E=\frac{1}{2}(b+c)
$$

Apabila frekuensi yang diharapkan kurang dari 5 maka pengujian yang digunakan yaitu uji binomial bukan uji McNemar. Untuk menguji hipotesis di atas digunakan statistik uji McNemar berikut ini:

$$
\chi^{2}=\frac{(|b-c|-1)^{2}}{b+c}
$$

$$
\text { Dimana: }
$$

$\mathrm{b}=$ Nilai sel $\mathrm{b}$ pada tabel McNemar

$\mathrm{c}=$ Nilai sel $\mathrm{c}$ pada tabel McNemar

Dengan menerapkan tes McNemar berpasangan dengan Koreksi Bonferroni. Koreksi Bonferroni diterapkan untuk mengurangi kemungkinan kesalahan tipe 1. Untuk mendapatkan nilai kritis koreksi Bonferroni, bagi nilai aasli dengan jumlah pengamatan.

$$
p=\alpha / k
$$

Nilai $p$ pembulatan dalam bentuk 3 desimal. Kemudian kriteria uji yang digunakan apabila nilai p-value yang dihasilkan dari uji McNemar lebih kecil daripada $p$ artinya terdapat perbedaan yang signifikan pada pasangan tersebut(8).

\section{Odds Ratio}

Odds ratio memastikan besar kecenderungan pada sebuah peluang yang berhubungan terhadap kelompok lain. Rumus odds ratio pada uji McNemar bisa dijabarkan sebagai berikut:

$$
\text { Odds ratio }=\frac{b}{c}
$$

Dimana:

$\mathrm{b}=$ Nilai sel $\mathrm{b}$ pada tabel McNemar

$\mathrm{c}=$ Nilai sel $\mathrm{c}$ pada tabel McNemar

Hasil dari odds rasio pada persamaan di atas kemudian dibandingkan dengan nilai 1 . Apabila odds ratio $>1$ kecenderungan berada pada atribut 1 , odds ratio $<1$ kecenderungan berada pada atribut 2 dan odds ratio $=1$ kecenderungan atribut 1 dan atribut 2 sama(9). 


\section{Hasil Penelitian dan Pembahasan}

Pada penelitian ini menjelaskan tentang menentukan atribut produk yang dianggap penting dalam membentuk citra merek produk suatu laptop oleh mahasiswa Program Studi Statistika FMIPA Universitas Islam Bandung melalui perbandingan proporsi tanggapan responden terhadap atribut yang dipilih. Terdapat beberapa atribut produk dalam membentuk citra merek produk suatu laptop. Atribut tersebut terdiri dari 5 atribut yaitu harga, warna, desain, merek, fasilitas dan spesifikasi.

Dalam penelitian ini data yang diperoleh dengan cara menyebar kuesioner dalam bentuk google form kepada 100 mahasiswa aktif Program Studi Statistika FMIPA Universitas Islam Bandung melalui link yaitu https://forms.gle/xLQjSA1aoLchwbhj9. Pertanyaan dalam kuesioner ini menggunakan skala nominal yang terdiri dari 2 pilihan jawaban yaitu dipilih dan tidak dipilih.

\section{Multiple Response Analisis (MRA)}

Untuk memenuhi uji Q Cochran, data akan dilakukan perhitungan MRA dalam mencari 3 pilihan atribut yang terbanyak. Data yang diperoleh kemudian dibentuk kedalam tabulasi sesuai dengan pemilihan atribut. Dengan pengkodean angka 1 yang artinya responden memilih atribut tersebut sedangkan angka 0 artinya responden tidak memilih atribut tersebut.

Tabel 2. Dummy Multiple Response Analisys mahasiswa Program Studi Statistika FMIPA Universitas Islam Bandung

\begin{tabular}{|l|l|l|l|l|l|l|}
\hline \multirow{2}{*}{$\begin{array}{l}\text { No } \\
\text { Responden }\end{array}$} & \multicolumn{6}{l}{ Citra Merek Produk Laptop } \\
\cline { 2 - 7 } & Harga & Warna & Desain & Merek & Fasilitas & Spesifikasi \\
\hline 1 & 0 & 1 & 1 & 0 & 0 & 1 \\
\hline 2 & 1 & 0 & 1 & 0 & 1 & 1 \\
\hline 3 & 0 & 0 & 1 & 1 & 0 & 0 \\
\hline$\ldots$ & $\ldots$ & $\ldots$ & $\ldots$ & $\ldots$ & $\ldots$ & $\ldots$ \\
\hline 100 & 1 & 0 & 1 & 1 & 1 & 1 \\
\hline jumlah & 69 & 35 & 74 & 42 & 57 & 89 \\
\hline Persentase & 69 & 35 & 74 & 42 & 57 & 89 \\
\hline
\end{tabular}

Dari tabel 2 tiga atribut yang paling banyak responden adalah Sepesifikasi, Desain dan Harga. Ketiga atribut tersebut menjadi dasar untuk pengujian uji Q Cochran.

\section{Uji Q Cochran}

Berdasarkan atribut Spesifikasi, Desain dan Harga akan dibandingkan proporsi tanggapan responden terhadap atribut yang dipilih. Dengan pengujian Q Cochran akan menghasilkan perbedaan proporsi tanggapan, hipotesis yang akan diuji adalah apakah ada berbedaan respon diantara ketiga atribut. Bentuk hipotesisnya sebagai berikut:

$\mathrm{H}_{0}: \pi_{1}=\pi_{2}=\pi_{3}$, ketiga atribut memiliki proporsi tanggapan sama

$\mathrm{H}_{1}$ : minimal 1 tanda sama dengan tidak berlaku, ketiga atribut memiliki proporsi tanggapan berbeda.

Menggunakan R Studio diperoleh Statistik uji Q = 11,404 dengan p-value = 0,003. Apabila taraf arti 5\% maka H0 ditolak karena p-value lebih kecil dari 5\%, sehingga dapat disimpulkan ketiga atribut memiliki proporsi tanggapan berbeda. Karena hasil uji Q Cochran signifikan, maka analisis post-hoc dilakukan melalui pengujian McNemar dengan koreksi bonferroni.

\section{Uji Lanjutan (Post hoc)}

Berdasarkan uji Q Cochran terdapat perbedaan proporsi tanggapan responden terhadap ketiga atribut yang dipilih. Selanjutnya akan di uji atribut mana saja yang berbeda tanggapannya satu sama lain. 
1. Pengujian Mcnemar dengan Koreksi Bonferroni

Bentuk hipotesis uji McNemar sebagai berikut: sama lain

$\mathrm{H}_{0}: \pi_{\mathrm{c}}=\pi_{\mathrm{b}}$, tidak ada perbedaan proporsi yang signifikan pada pasangan atribut satu

$\mathrm{H}_{1}: \pi_{\mathrm{c}} \neq \pi_{\mathrm{b}}$, ada perbedaan proporsi yang signifikan pada pasangan atribut satu sama lain

Dari hasil perhitungan nilai harapan sesuai dengan persamaan 2.2 mendapatkan hasil nilai harapan yang lebih dari 5, maka pengujiannya bisa menggunakan McNemar karena nilai harapan menunjukan sampel besar. Untuk hasil pengujian McNemar memperolehan hasil dari $\chi^{2}$ dan nilai $p$-value dapat dlihat dari tabel 3 tabel.

Tabel 3 Hasil Pengujian McNemar

\begin{tabular}{|c|c|c|}
\hline Pasangan Atribut & Statistik uji & P-value \\
\hline $\begin{array}{c}\text { Spesifikasi } \\
\text { dengan Harga }\end{array}$ & 10,618 & 0,00112 \\
\hline $\begin{array}{c}\text { Spesifikasi } \\
\text { dengan Desain }\end{array}$ & 5,2973 & 0,02136 \\
\hline $\begin{array}{c}\text { Desain dengan } \\
\text { Harga }\end{array}$ & 0,37209 & 0,5419 \\
\hline
\end{tabular}

Berdasarkan hasil pengujian McNemar dengan jumlah pengujian sebanyak tiga pasang atribut $(\mathrm{k}=3)$, maka diperoleh koreksi bonferroni sebesar $\alpha / \mathrm{k}=0,017$. Koreksi bonferroni digunakan untuk meminimalisisr kesalahan tipe 1 . Selanjutnya nilai tersebut dibandingkan dengan hasil pengujian McNemar diperoleh sebagai berikut:

Tabel 4 Hasil Pengujian McNemar

\begin{tabular}{|c|c|c|l|}
\hline Pasangan Atribut & Statistik uji & P-value & \multicolumn{1}{|c|}{ Keterangan } \\
\hline Spesifikasi dengan Harga & 10,618 & $0,00112^{*}$ & $\begin{array}{l}\text { Tanggapan spesifikasi } \\
\text { dan harga berbeda }\end{array}$ \\
\hline Spesifikasi dengan Desain & 5,2973 & 0,02136 & $\begin{array}{l}\text { Tanggapan spesifikasi } \\
\text { dan desain sama }\end{array}$ \\
\hline Desain dengan Harga & 0,37209 & 0,5419 & $\begin{array}{l}\text { Tanggapan desain dan } \\
\text { harga sama }\end{array}$ \\
\hline
\end{tabular}

Keterangan: *) signifikan pada $\alpha=0,017$

Menurut hasil dari perbandingan McNemar dengan koreksi bonferroni diatas menunjukan bahwa pasangan atribut Spesifikasi dengan Harga memiliki perbedaan proporsi yang signifikan Artinya pasangan yang memiliki perbedaan proporsi yang signifikan terdapat pada pasangan harga dan spesifikasi.

2. Odds Ratio

Ketika perbedaan telah didapatkan dengan uji McNemar, maka odds ratio digunakan untuk menghitung seberapa besar hubungan dari 1 pasangan atribut yang dipilih responden. Odds ratio juga memastikan besar kecenderungan pada sebuah peluang yang berhubungan terhadap kelompok lain. Untuk mengetahui seberapa besar peluang dari odd ratio bisa digunakan dentgan persamaan (2.6).

Odds ratio $=27 / 7=3,86$ 
Dari hasil perhitungan odds ratio diatas menghasilkan nilai odds ratio sebesar 3,86. Dari hasil pebandingan nilai odds ratio dengan 1 atau 3,86>1 artinya kecenderungan berada pada atribut spesifikasi lebih penting sebesar 3,86 kali dari atribut harga. Dari hasil perbandingan diatas menunjukan bahwa atribut yang dianggap paling penting dalam membentuk citra merek produk suatu laptop adalah spesifikasi.

\section{Kesimpulan}

Berdasarkan hasil perhitungan dan pembahasan mengenai pengujian proporsi tanggapan responden mengenai atribut produk yang dianggap penting dalam membentuk citra merek produk suatu laptop dengan pengujian Q Cochran menggunkan metode Multiple Response Analysis (MRA) yang diaplikasikan terhadap data yang diperoleh dari hasil kuesioner mahasiswa Program Studi Statistika FMIPA Universitas Islam Bandung, menghasilkan kesimpulan sebagai berikut:

1. Berdasarkan hasil MRA diperoleh tabulasi data yang berupa jumlah hasil jawaban responden yang memperoleh tiga atribut tertinggi yaitu Spesifikasi, Harga dan Desain.

2. Hasil dari pengujian $\mathrm{Q}$ Cochran dengan taraf arti 5\% dapat disimpulkan atribut Spesifikasi, Harga dan Desain memiliki proporsi tanggapan yang berbeda dari responden.

3. Hasil perbandingan Koreksi Bonferroni dengan p-value McNemar menunjukan, terdapat satu pasangan memiliki perbedaan proposi tanggapan responden yang signifikan yaitu pasangan atribut Spesifikasi dengan Harga.

4. Dari hasil odds ratio menunjukan, kecenderungan memilih atribut Spesifikasi 3,86 kali lebih besar dari atribut Harga. Dengan kata lain bahwa dalam kasus ini Spesifikasi merupakan atribut yang dianggap paling penting dalam membentuk citra merek produk pada suatu laptop.Berdasarkan pembahasan dalam penelitian ini, peneliti menyimpulkan beberapa hasil penelitian sebagai berikut:

\section{Acknowledge}

Penulis mengucapkan terima kasih banyak kepada berbagai pihak yang telah memberi arahan serta dukungan kepada penulis terutama kepada ibu Teti Sofia Yanti, Dra., M.Si. yang telah membimbing penulis dalam proses penyelesaian penelitian ini. Dengan ini penulis hanya dapat memberikan doa dan sampaika terima kasih, semoga hasil dari penelitian ini dapat bermanfaat bagi pembaca khususnya bagi penulis.

\section{Daftar Pustaka}

[1] 1. Stephen D, Adruce SAZ. Cochran's Q with pairwise McNemar for dichotomous multiple responses data: A practical approach. Int J Eng Technol. 2018;7(3):4-6.

[2] 2. Durianto dkk. Menaklukan Pasar melalui Riset Ekuitas dan Perilaku Merek. Jakarta: Jakarta:PT Gramedia Pustaka Utama; 2001.

[3] 3. Fandy T. Strategi Pemasaran. Yogyakarta: Yogyakarta:Andi Offset; 1997. 103 p.

[4] 4. Ganwarin MEM. Analisis Atribut-Atribut yang Menentukan Konsumen Dalam Pembelian Laptop. Universitas Sanata Dharma; 2009.

[5] 5. International Business Machines Corporation. Multiple responses analysis [Internet]. IBM Corporation. 2016 [cited 2020 Jul 26]. Available from: https://www.ibm.com/docs/en/spss-statistics/24.0.0?topic=base-multiple-response-analysis

[6] 6. Siegel S. Statistik Nonparametrik Untuk Ilmu-Ilmu Sosial. Jakarta: Jakarta: PT Gramedia Pustaka Utama; 1992. 202 p.

[7] 7. Heryana A. Uji McNemar dan Uji Wilcoxon (Uji Hipotesa Non-Parametrik Dua Sampel Berpasangan). Catatan Ade Heryana [Internet]. 2017;(May):3-8. Available from: http://adeheryana.weblog.esaunggul.ac.id/2017/05/21/uji-monemar-dan-uji-peringkatbertanda-wilcoxon-pada-dua-sampel-berpasangan/

[8] 8. Solution S. Bonferroni Correction [Internet]. Complete Desetation. 2021 [cited 2020 Jul 26]. Available from: https://www.statisticssolutions.com/bonferroni-correction/ 
134 | Dilla Oktoriandi.

[9] Fay MP. Exact McNemar' s Test and Matching Confidence Intervals. Psychometrika. $2020 ; 1-4$. 